\title{
The Stairs Fleet of Halifax: 1788-1926
}

\section{James D. Frost}

Malgré la renaissance d'études de l'histoire des Maritimes qui a fleuri au cours des dernières trente-cinq années, il n'y a pas encore de corps de travail important dans l'histoire du commerce dans les Maritimes. Il y a peu d'études sur les propriétaires de navires, les banques, les industries, ou même des entrepreneurs de cette région. Il existe de nombreuses synthèses étendues, mais un étonnant manque d'études de cas dans les Maritimes ou en Nouvelle-Écosse. Sauf pour les histoires d'entreprise de la Banque de Nouvelle Écosse et de la Banque Royale, il n'existe pas d'études scientifiques de la contribution de la région au système bancaire canadien, à l'exception de l'étude modeste de la Banque de Nouvelle Écosse faite par le présent auteur. Le projet marine marchande du Canada atlantique a réalisé un travail exemplaire sur l'industrie maritime de la région, mais peu d'analyse en profondeur de propriétaires d'un seul navire. Ce document est basé sur une recherche effectuée pour une biographie de la famille Stairs de Halifax, publiée en 2003. Il est conçu comme un examen en profondeur de propriétaire d'un seul navire, dans le cas présent d'une famille de tels propriétaires.

In spite of the ground-breaking work of the Atlantic Canada Shipping Project and the related Maritime History Group in rewriting the history of shipping and shipbuilding in Canada's Maritime provinces ${ }^{1}$, with one or two exceptions, individual owners or families have so far been ignored. ${ }^{2}$ This paper will examine the activities of one such

1 The most extensive study to date is Eric W. Sager and Gerald E. Panting, Maritime Capital: The Shipping Industry in Atlantic Canada, 1820-1914 (Montreal and Kingston, 1990). Two succinct summaries are provided in Eric W. Sager and Lewis W. Fischer, "Atlantic Canada and the Age of Sail Revisited", Canadian Historical Review LXIII (June 1982), 125-50, reprinted in The Northern Mariner/Le marin du nord XVII, no. 4 (October 2007), 1-22; and Eric W. Sager and Lewis W. Fischer, Shipping and Shipbuilding in Atlantic Canada, 18201914, Canadian Historical Association Booklet No. 42 (Ottawa, 1986). For an extensive summary of the genre see Lewis R. Fischer, "The Enterprising Canadians: An Assessment of Canadian Maritime History since 1975" in Frank Broeze, ed., Maritime History at the Crossroads, Research in Maritime History No. 9 (St. John's, 1995).

2 An exception is Lewis R. Fischer, “An Engine Yet Moderate': James Peake, Entrepreneurial Behaviour and the Shipping Industry of Nineteenth Century Prince Edward Island," in Lewis R. Fischer and Eric W. Sager, eds., The Enterprising Canadians, Entrepreneurs and 
family, the Stairs of Halifax, during a period that stretched over a century. After a halting start they were present in the Halifax business community almost continuously from 1775 to 1973 and if it had not been for the last family business leader becoming ill with ALS when his son was only fifteen, they might yet be a presence $\mathrm{n}$ the city. The family started as general merchants, began to specialize in chandlery and eventually became bankers, industrialists, and finance capitalists. The Stairs family, unlike many other contemporary businesses engaged in shipping and ship owning, made the transition from sail to steam and wood to steel construction. As financiers to the province's burgeoning steel-making industry, they also took a role in local attempts to establish steel shipbuilding in Nova Scotia. ${ }^{3}$

As medium-sized shipowners who became involved in the shipping business to support their other activities, most notably their ship chandlery business, the Stairs represent a good test for many of the paradigms established by the Atlantic Canada Shipping Project and other studies. ${ }^{4}$ The paper is based on extensive research at the Maritime History Archive in St. John's, NL and the Stairs fonds at Nova Scotia Archives and Records Management. Voyage data was compiled from ships' logs, the diaries of William Stairs and Lloyd's List.

\section{Beginnings}

The early descendants of the Stairs family arrived in Nova Scotia eager to take advantage of available business opportunities. John Stairs, who was the first member of the family known to have settled in Halifax, was the son of Hannah Roe and John Steers, who were married in Philadelphia in 1749. ${ }^{5}$ John's presence in Halifax was first recorded

Economic Development in Eastern Canada, 1820-1914 (St. John's, 1979). See also, Richard Rice, "The Wrights of Saint John: A Study of Shipbuilding and Shipowning in the Maritimes, 1839-1855," in David S. Macmillan, ed., Canadian Business History, Selected Studies, $1497-$ 1971 (Toronto, 1972).

3 See James D. Frost, "The Aborted British Invasion: The Case of Swan Hunter Shipbuilders, 1899-1915," Journal of the Royal Nova Scotia Historical Society (1999).

4 This phenomenon has been explored elsewhere by Lewis R. Fischer and Anders M. Fon, "The Making of a Maritime Firm: The Rise of Fearnley and Eger, 1869-1917," in Lewis R. Fischer,ed., From Wheel House to Counting House: Essays in Maritime Business History in Honour of Professor Neville Davies (St. John's, 1992), 303-322, and Lewis R. Fischer and Helge W. Nordvik, "The Growth of Norwegian Shipbroking: The Practices of Fearnley and Eger as a case Study, 1869-1914," in Lewis R. Fischer and Walter Minchinton, eds., People of the Northern Seas (St. John's 1993), 135-155.

5 The family's lineage is much disputed. See James D. Frost, Merchant Princes: Halifax's First Family of Finance, Ships and Steel (Halifax, 2003); Nova Scotia Archives and Records Management [NSARM] MG1, vol. 160A, William Marsters Brown papers, notebook, 1882; Family History: Stairs, Morrow (Halifax: McAlpine Publishing, 1906); H. G. Stairs, "The Stairs of Halifax," unpublished manuscript, 1962; NSARM, MG1, vol. 1642, no. 207, Charles Stayner Papers, "The Stairs Family," Consolidation, 21 February 1977. New evidence indicates Hannah Roe married John Steers in Philadelphia in March 1749. "Pennsylvania Marriage Licenses, Pennsylvania Vital Records," Pennsylvania Magazine of 
in 1775 , when his name appears on the assessment list. He was assessed $£ 100$ and taxed $8 \mathrm{~s} 6 \mathrm{~d} .{ }^{6} \mathrm{He}$ established some kind of "commercial pursuit," and is listed in a 1785 Halifax property deed as a "merchant." He may have been an early pioneer in the Nova ScotiaWest Indies trade, as trade between those areas soared after the American Revolution. ${ }^{8} \mathrm{He}$ may have had connections in Grenada through his mother, Hannah, who had gone there sometime in the 1760s. ${ }^{9}$ Though John never figured amongst the most prominent merchants of Halifax, by 1787-88 he was sending cargoes of fish, hogsheads (barrels), salmon, shingles, lumber and cod liver oil to Grenada, in exchange for rum, on a vessel called Joanna, undoubtedly named for his wife or daughter, and in which he probably had an interest. ${ }^{10}$ Much of what John was shipping to Grenada was either to construct houses for slave masters, or to make containers to export sugar and molasses and other commodities to Britain, and much of the food went to feeding slaves. In 1788, John successfully petitioned the Nova Scotia government for a rebate of $£ 22$ duty which he had been wrongly forced to pay on a shipment of rum.

Like some other Halifax merchants, John was sometimes forced to take out judgements to collect many of his accounts. At the same time, there were frequent judgements against him. In 1785, he obtained a judgement against Ebenezer Livesay for $£ 24-4-6$, which, with costs, amounted to £31-17-10 and John later had Livesay imprisoned for this debt. On 4 March 1787, six prisoners broke out of the Halifax jail, with five being recaptured. Livesay escaped and was never seen again. John himself sued Francis Green, high sheriff of the County of Halifax, for £31-17-10, the amount of his judgement in the same lawsuit, because Green had allegedly let Livesay out of jail. Jonathan Stearns appeared for John and S.S. Blowers, and on 30 July 1787 the Justice found for the plaintiff. ${ }^{11}$ John was awarded his debt and costs, in the amount of £44-14-2. This action caused some consternation in the Legislative Council where Green was wellconnected, but when the sheriffs were named in 1788, he was not re-appointed.

John himself was also briefly confined in debtor's prison in 1787, when the suit of Anthony Stewart v. John Stairs was brought forward. In 1788 John successfully sued James Bowen of Jeddore for nonpayment in the sale of a fisherman's shallop, for which he was awarded $£ 70$. That autumn, he was awarded another $£ 100$ when he sued another fisherman from Halifax for reasons unidentified. In January 1790, Robert Hall sued him

History and Biography, I (1993), 519.

6 NSARM, MG1, vol. 411; Charles Stayner Papers, "The Stairs Family", Consolidation, 21 February 1977.

7 The reference to "commercial pursuits" is in Family History; NSARM, Stairs Deeds, vol. 1, 1749-1836, index reel 17811.

8 Selwyn H.H. Carrington, "The United States and Canada: The Struggle for the British West Indian Trade," in "Caribbean Economic History," B.W. Higman, ed., special issue, Social and Economic Studies, 37, nos. 1\&2 (March-June 1988).

9 Grenada Archives, Grenada Supreme Court, Registry, Deed Book A1 pp 307-309, Indenture, 12 February 1765.

10 Grenada Archives, Colonial Office documents 106/2, 88.

11 Phyllis R. Blakeley, "Green, Francis" in Dictionary of Canadian Biography, Volume V: 1801-1820 (Toronto, 1983), 389-390; Charles Stayner Papers, "The Stairs Family." 
for $£ 19-17-9$ for 100 gallons of spirits, for which John had promised to pay but had not. ${ }^{12}$

In 1788, John had apparently shipped thirty barrels of mackerel and one barrel of cod fish to Grenada, which had arrived in a putrefied state. According to testimony received three years later, "from appearances there was nothing but salt water put in the barrels to save the mackerel and codfish."13 Most of the judgements for or against Stairs were for twenty or thirty pounds sterling; the only larger one was in an action he brought against several prominent men, including Henry Newton, Jonathan Binney, James Kavanaugh, Robert Myers and Thomas Pye, in October 1790, in which he was awarded $£ 240$ and costs of $£ 12-18-2$, but which was later set aside when they alleged that John "had collaborated with certain persons unknown to the defendants in order to charge them with trespass." ${ }^{\prime 4}$ The judgements against John seem to increase as time went on with the last one being 29 December 1791, when Samuel Sparrow obtained another judgement for $£ 19-9-2$ with costs of $£ 10-17-8$. This was one day after John sold his waterfront property to the mortgagee, Edward Pryor, for $£ 130 .{ }^{15}$

John may have retired from "merchanting" or made some modest profits by his commercial pursuits, as a 1791 property deed identifies him as a "gentleman," which could indicate he had abandoned his commercial pursuits. About 1791-92, however, John somehow "lost his means." 16 He had owned at least one ship outright, a brig called Admiral Hughes which was built for him at Beaver Harbour, Nova Scotia in 1789. On 23 February 1790, it sailed for North Carolina, and returned in May via New Providence in the Bahamas, after which no data can be found. Perhaps this vessel was lost or perhaps the judgement in which the $£ 240$ award originally intended for him was denied, had a debilitating effect on his cash flow. About 1791-92, however, John fell on hard times and after a stay in debtor's prison, he left Halifax and settled in Philadelphia in 1793, where his luck did not improve.

\section{The ships of William Stairs, 1826-45}

The next generation of Stairs merchants was more fortunate. William Stairs was born in 1789, the son of John and Joanna Stairs. At age 8, William Stairs was sent from Philadelphia to Halifax to live with his uncle John Stayner, after his mother died of yellow fever. After apprenticing to the Scottish merchant William Kidston in 1810, William Stairs established his own general store on Bedford Row in Halifax. His business flourished during the War of 1812, but almost went bankrupt in the aftermath. By the early 1820s, he was a rising merchant and began to diversify. Between 1826 and 1845 ,

12 NSARM, RG 39C, vol. 54, no. 39, Timothy Sullivan v. John Stairs, 7 January 1788; RG 39 C, vol. 54, no. 29, John Stairs v. James Bowen, 1 April 1788.

13 NSARM, RG 39 C, vol. 54, no. 30, John Stairs v. John Pettypaw, 26 September 1788; RG 39 C, vol. 54, no. 28, John Stairs v. John Boodro, 26 September 1788.

14 NSARM, RG 39C, vol. 64, no. 51-9, Samuel Sparrow merchant v. John Stairs, 4 October 1790.

15 Charles Stayner Papers, "The Stairs Family"; NSARM, Registry of Deeds, John and Joanna Stairs to Edward Pryor, 1791, no. 82, book 29, 200, reel 17879.

16 William J. Stairs, "Stairs Family History," in Family History: Stairs, Morrow, 1. 
William owned all or part of nine vessels, ranging in size from 76 to 474 tons, totalling 962.15 tons. His fleet consisted of three full-rigged ships, three brigs, two schooners and two barques (Corsair's rig was changed from brig to barque in 1838). With the exception of his first vessel, Atlantic, and perhaps Rachel and Ellen and Trial, Stairs and his partners, who were other local entrepreneurs, tended to own their vessels longer than many of their contemporaries, averaging 5.55 years; he held on to both Corsair and Halifax for over ten years during the prosperous 1830s and bought both new and old vessels as the opportunity arose. "Buying Cheap and Selling Dear" does not appear to have applied to his fleet. ${ }^{17}$

Stairs' first vessel was Atlantic, built in 1826 by Thomas Louden of Dartmouth. His partners were fellow trustees in the Halifax Packet Company, James Bain, Lawrence Hartshorne, James N. Shannon, and James McNab. The Halifax Packet Company, or Halifax and Liverpool Trading Company, was organized in 1825 to run the first nongovernment packet service between Nova Scotia and the United Kingdom. The idea was to trade fishery products for manufactured goods, with "cabins to be fitted up elegantly to carry passengers." 18 Whether this proved worthwhile is not known. Atlantic was shiprigged and weighed 331 tons. Stairs sold his 2/64 shares to James Bain in June of 1829, by which time he had "retired" from the committee of management of the Packet Company. He built only one other vessel, Halifax, with the Halifax Packet Company, but three other vessels with Joseph E. Fairbanks and James McNab, one of whom was a partner in the Halifax Packet Company. ${ }^{19}$

Fairbanks and McNab were major shipowners in their own right, individually and as partners, and were also later associated with the Shubenacadie Canal project, which aimed at building a canal to link Halifax Harbour with the Bay of Fundy. The same partners, as well as two others, Andrew Russel and William Foster, built and owned Corsair, a 282 ton brig, from 1826 to $1841 .^{20}$

Stairs mentions Corsair many times in his diary, "landing at the wharf" (his father-in-law Stayner's) in April 1828, sailing for Liverpool the day before Christmas, and again the next May. The vessel made the trip from Halifax to Liverpool in MarchApril 1830 in only 20 days. In June 1833, it arrived back in Halifax after a voyage of 74 days, and was loaded with a cargo of 51,285 board feet (bf) of lumber, eventually sailing for Liverpool September 21. It did not return until October 1834, when it was loaded with a cargo of lumber, "bog oil," sugar, wine and salt for Demerara. In March 1835 it sailed

17 NSARM, MG1, series E, vol. 3265; See Eric W. Sager, "Buying Cheap and Selling Dear: Merchant Shipowners and the Decline of the Shipping Industry in Atlantic Canada,", in Canadian Papers in Business History, Vol. 1, Peter A. Baskerville, ed. (Victoria: Public History Group, University of Victoria, 1989), 59-74.

18 Novascotian (Halifax), 4 May 1825.

19 Maritime History Archive, Memorial University of Newfoundland [MHA], Certificate of British Registry; Lloyd's Register, 1829; David Sutherland, "The Merchants of Halifax, 18151850: A Commercial Class in pursuit of Metropolitan Status" (PhD dissertation, University of Toronto, 1975), 150-151.

20 MHA, Owner and Vessel Registry; ibid., Certificate of British Registry. 
for Liverpool with 45,686 bf of spruce and birch. In July Stairs shipped another 60,000 bf of softwood and hardwood. ${ }^{21}$ Corsair continued as one of Stairs' workhorses, mainly carrying lumber, until he sold his share for an undetermined amount of money to Fairbanks and McNab in 1841.

Stairs also owned a number of vessels on his own account: Rachel and Ellen, a small brig of 98 tons; Rambler, a schooner of 76 tons; Trial, another brig of 158 tons; and Cornwall, another schooner of 176 tons. These vessels were owned for comparatively short periods of time, the longest being Cornwall, which he owned for four years, 184145. None of these vessels are mentioned in William's diary, with the exception of Trial loading 74,313 bf of lumber in December $1840 .{ }^{22}$ It is likely these vessels were used either to run back and forth to the West Indies, or more likely, delivering goods for his store around the coast of Nova Scotia and perhaps Newfoundland.

John Porter was a 238 ton ship-rigged vessel which William owned, along with Fairbanks and McNab, from 1833 to 1840. It was built at Quebec City in 1829. William's younger son John wrote his older brother W.J., "she is a fine vessel of three hundred tons, and stands letter A. No. 1 at Lloyd's." ${ }^{23}$ From the scanty evidence, the vessel appears to have sailed a triangular route between his lumber yard in Dartmouth, the U.K. and the West Indies, mostly engaged in the lumber trade. John Porter was able to load up to 98,042 bf of lumber. Occasionally, it would carry a mixed cargo of oil and lumber. It stayed in William's and his partners' service until 1840, when it was driven ashore at the entrance to St. Mary's Harbour and wrecked. ${ }^{24}$ William's largest vessel, also owned with Fairbanks and McNab, was Clio, a barque of 474 tons, originally built at Parrsboro in 1824, but acquired by them in 1837. It remained in their fleet until 1843, when it was sold in Liverpool. ${ }^{25}$ Clio carried mostly lumber outbound, but also delivered wheat on at least one occasion inbound, probably from the U.S. East Coast.

Though William Stairs expanded his business activities significantly during this period, other Halifax shipowners in this early period were much larger and richer. Samuel Cunard, for instance, built dozens of vessels from 1813 until 1856, well after he had left for the U.K. to start a transatlantic steamship service. ${ }^{26}$ Other notable Halifax owners included John Starr, William Pryor, William and George Lawson, John Fairbanks, James McNab, James Forman, and James Bain, several of whom were William's partners in the Halifax Packet Company. ${ }^{27}$ Stairs likely invested in ships because it gave him the

21 NSARM, MG1, series E, vol. 3265, folder 2, "Business and Personal Diary" of William Stairs, 1827-39.

22 MHA, Certificate of British Registry; William Stairs diary.

23 Lloyd's Register, 1836; MHA, Certificate of British Registry; NSARM, MG1, vol. 3250, folder 1, John Stairs to William J. Stairs, 11 February 1833.

24 William Stairs diary.

25 MHA, Certificate of British Registry; Lloyd's List; William Stairs diary.

26 MHA, Halifax Data Base; Francis E. Hyde, Cunard and the North Atlantic, 1840-1973 (London, 1975).

27 MHA, Halifax Data Base. 
opportunity to diversify his business interests beyond general merchandise.

\begin{tabular}{|c|c|c|c|c|c|c|c|}
\hline $\begin{array}{l}\text { Vessel } \\
\text { Name }\end{array}$ & Rig & Tonnage & $\begin{array}{l}\text { Years } \\
\text { Owned }\end{array}$ & Owner(s) & $\begin{array}{l}\text { No. Shares } \\
/ 64\end{array}$ & $\begin{array}{l}\text { Tons } \\
\text { Owned }\end{array}$ & Partners \\
\hline Atlantic & ship & 331 & 1826 & William Stairs & 12 & 62.06 & Hfx Packet Co \\
\hline Corsair & $\begin{array}{l}\text { brig / } \\
\text { bk }\end{array}$ & 282 & $1826-41$ & $"$ & 16 & 75.75 & $\begin{array}{l}\text { Fairbanks/Foster/ } \\
\text { McNab/Russel }\end{array}$ \\
\hline Halifax & ship & 344 & $1828-38$ & " & 6.4 & 34.40 & Hfx. Packet Co. \\
\hline $\begin{array}{l}\text { Rachel }+ \\
\text { Ellen }\end{array}$ & brig & 98 & $1829-30$ & $"$ & 64 & 98.00 & none \\
\hline $\begin{array}{l}\text { John } \\
\text { Porter }\end{array}$ & ship & 238 & $1829-40$ & $"$ & 32 & 119.00 & Fairbanks / McNab \\
\hline Rambler & sch & 76 & $1832-35$ & $"$ & 64 & 76.00 & none \\
\hline Clio & bk & 474 & $1837-43$ & $"$ & 22 & 162.94 & Fairbanks / McNab \\
\hline Trial & brig & 158 & $1838-40$ & $"$ & 64 & 158.00 & none \\
\hline \multirow[t]{2}{*}{ Cornwall } & $\operatorname{sch}$ & 176 & $1841-45$ & $"$ & 64 & 176.00 & none \\
\hline & & & & & & 962.15 & \\
\hline
\end{tabular}

\section{Table 1: William Stairs Vessels}

William stayed away from ship-owning after 1845, except for his purchase of the 176 ton schooner Cornwall, which he owned from 1841 until 1845, and which was likely used in the coasting or West Indies trades. Colonial shipping and lumber were hard hit by the repeal of Britain's Corn Laws in 1846 and Navigation Acts in 1849, which opened up British shipping and trade to foreign fleets. ${ }^{28}$ Timber duties were modified beginning in the 1840s, but were not slashed seriously until mid-decade. Especially hard hit was Nova Scotia's West Indies trade. As astute as he was, William was likely cognizant of the impact of these duties and stayed away from ship-owning until 1853, when he purchased Rose, a schooner he bought with his son W.J.

William Stairs also played a major role in the Halifax Steam Boat Company, which was formed in 1815 to provide ferry service across Halifax Harbour between Halifax and Dartmouth. Sherbrooke was built in 1816 and was able to carry cattle, carriages and horses, and represented a vast improvement over its predecessors. Built in 1829, Sir Charles Ogle was the first steam boat built in Nova Scotia, in Alexander Lyle's shipyard in Dartmouth. It served the community for over sixty years. Samuel Cunard took over the presidency of the fledgling Halifax Steamboat Company in 1836, and its fortunes immediately improved. A second steamboat, Boxer, was launched in 1838, with a new engine capable of producing $25 \mathrm{bhp}$. Boxer only lasted 27 years, as the vessel was of

28 Sager, Maritime Capital; Charles Armour and Thomas Lackey, Sailing Ships of the Maritimes, 1750-1925 (Toronto, 1975); Nicholas de Jong and Marvin E. Moore, Shipbuilding on Prince Edward Island, Enterprise in a Maritime Setting, 1787-1920 (Ottawa, 1994). 
inferior design compared with its predecessor. Both vessels were joined in 1844 by Micmac, which operated until $1901 .{ }^{29}$ William's interest in shipping waned as he became involved in politics and concentrated on developing the family firm. In the mid-1850s, after a fishing trip to Nova Scotia's Musquodoboit Valley, he also found time to establish a bank, the Union Bank of Halifax (purchased by the Royal Bank of Canada in 1910).

\section{Building the family fortune, $\mathbf{1 8 6 0 - 8 5}$}

The so-called "Golden Age" of Nova Scotia is generally considered to have begun with U.S. Reciprocity in 1854. Surprisingly, William's son W.J. Stairs did not begin to invest the family's money in ships again until 1860 . The family firm, now called William Stairs, Son and Morrow (WSS\&M) had begun to specialize in ship chandlery.

After the family did begin to invest in ships again, William J. Stairs owned shares in at least 25 vessels personally, usually buying a quarter or half the shares, and occasionally all $64 .{ }^{30} \mathrm{He}$ also owned a variety of vessels, including schooners, barques, brigs and full-rigged ships. Most of the vessels in which he invested were built in Maitland, New Glasgow, or on the South Shore of Nova Scotia. The shareholding patterns reflect a remarkable amount of cross-community co-operation, both in terms of risk-taking and profit-making. The shipbuilding expertise and raw materials were located in the rural parts of the province, whereas capital to build the vessels was often available in the larger centres such as Halifax, New Glasgow and Yarmouth. His partners often included the builder and his family, as well as the master of the vessel and his family. $\mathrm{He}$ also took shares in a vessel in lieu of payment for outfitting, or he inherited a share in a vessel because an owner defaulted on his credit to WSS\&M. Motivation for investment in shipping was probably twofold: to earn income from the vessel, but also to develop relationships with owners and builders for the sake of the company's chandlery business.

Shipping agency work was another aspect of the firm's chandlery business. WSS\&M "were appointed as managing owners to chandle [sic] the ships and to sell the goods which the ships brought back from the four corners of the world." 31 The agency or "consignment" business likely grew out of representing Kidston \& Co., the firm founded by William's old employer, who had long since moved back to Scotland. It appears that both the cargo and the vessel were, in most cases, consigned to the same company, a procedure identical to the shipping "agency" business. Many of the companies to whom vessels were "consigned" were indeed shipping agencies. The Kidston vessel Roseneath was a fixture in Halifax every spring and autumn from 1857 to 1882 . Roseneath was also

29 Joan and Lewis Payzant, Like a Weaver's Shuttle, A History of the Halifax-Dartmouth Ferries (Halifax, 1979).

30 Stairs family tradition suggests that the Stairs family owned a mere 32 sailing vessels. This number appears often in the correspondence of both Cyril W. Stairs and Arthur D. Stairs, who ran WSS\&M after 1926. It also appears in many official company brochures. With the assistance of the Maritime History Archive in St. John's, we have been able to establish the existence of a much more extensive fleet.

31 NSARM, MG 1, vol. 3258, folder 11, Arthur D. Stairs to A.E. Carpenter, editor of The Houghton Line, 11 June 1957. 
remarkable in that it was the first iron ship to sail into Halifax Harbour. It was a packet (a vessel which kept a regular schedule) of 739 tons, and would often spend a month in port unloading an extensive cargo of general merchandise. A typical cargo included 16 bundles of hoop iron, one bale of general merchandise, 68 winches, 393 bales of hemp yarn, 175 castings, 260 bundles of sheet iron, 113 bars of iron, 45 bales and a "quantity of junk." Other cargo for an assortment of merchants included whiskey, wine and rum. Roseneath would return to Glasgow either via Sydney (where it would load coal destined to Montreal), Philadelphia (where it would load petroleum), or Savannah (where it would pick up a cargo of cotton). ${ }^{32}$

By 1860, W.J. Stairs was firmly in control of WSS\&M, having taken over its management in 1855 when his father founded the Union Bank of Halifax. He became a significant player in the Halifax fleet starting in 1860. Between 1860 and 1869 he owned shares in one schooner and six barques, ranging in size from 90 to 713 tons, totalling 1,118 tons altogether. They were owned an average of eight years, with the longest-held, William, named in honour of his beloved first son, who died at age 14 the same year the ship was built. William was in the fleet for 19 years, from 1869 to 1888. W.J.'s first vessel was the $W$. Stairs, a 90 ton schooner built in Fogler's Cove, Nova Scotia in 1859. It was probably a coastal schooner, as all of the voyage data for 1860-61 list Halifax as the port of call. It was sold to the Pryor family of Halifax, who owned the craft for another four years. $^{33}$

Viking was a much more ambitious project, which brought W.J. together with the great New Glasgow shipbuilder J.W. Carmichael, as well as William Chisholm, and Jeffrey McColl of Pictou. Viking was a barque of 598 tons, built by Carmichael at New Glasgow in 1862, and broadened the Stairs' horizons by being their first exposure to global trading. During its first year, Viking traded transatlantic. By 1864 the vessel had visited Sydney, Australia, and Rangoon, Burma, before returning to Falmouth, England, and Portland, Maine. In 1865, it sailed to Montevideo, Uruguay and Surabaya, Indonesia. By the summer of 1866 Viking had returned to Philadelphia, and by the fall was in Boston. ${ }^{34}$ Unfortunately, information about the cargoes carried on these voyages and their contribution to the Stairs' overall enterprises is not available.

Alice Roy was a 610 ton barque built in 1866 for W.J. and his partners, including Thomas Douglas, at Maitland, NS. It cost $\$ 41.09$ per ton to build, or about $\$ 25,064$. After launching, Alice Roy sailed for Liverpool. It made three transatlantic voyages during 1866-67, before sailing for the Mediterranean and Black Sea in 1868 to pick up grain. The vessel returned to the Atlantic in 1869, including a brief stop in Halifax, before embarking on a voyage to Montevideo, Uruguay, where it probably picked up a cargo of grain. For the next ten years, Alice Roy sailed the North Atlantic, between either the United Kingdom or Antwerp/Rotterdam/Bremerhaven and Philadelphia/Savannah. It may

32 NSARM, Pickford and Black papers; Morning Chronicle (Halifax), various issues, 1876-82; NSARM, MG1, vol. 3252, folder 1, W.H. Browne to Cyril W. Stairs, 11 March 1932.

33 MHA, Owner and Vessel Registry; ibid., Certificate of British Registry; Lloyd's List, 186062. 


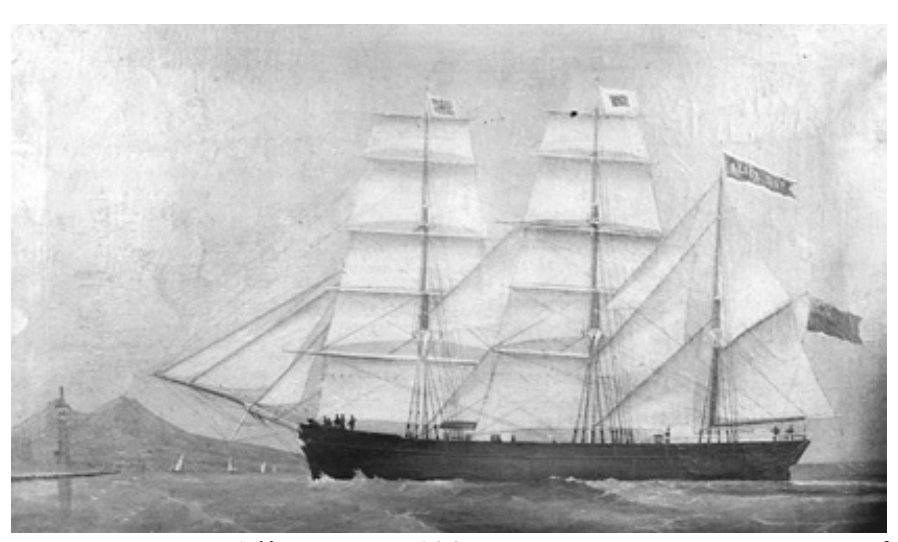

Illustration 1: Alice Roy, 610 tons, Maritime Museum of the Atlantic. have carried cotton from Savannah and perhaps petroleum from Philadelphia, although the vessel was relatively new to be carrying such dangerous cargo. Westbound, the vessel may have carried some immigrants, and lower valued cargo, since steam vessels were making major incursions by this time. Typical of other vessels from the Maritimes, in 1880-81 Alice Roy made two trips

from Montreal to Buenos Aires, as sail could still compete with steam on longer voyages. It foundered on a rock at the Pilgrims, near the entrance to the St. Lawrence, in 1881, was pumped out, towed to Quebec and sold for $\$ 2,500 .^{35}$

William was a large barque of 713 tons displacement, built at Cornwallis, near Kentville, NS for W.J. Stairs, Decker, Harding and David M. Dickie of Canning, which they owned from 1869 to 1888 . It cost $\$ 42.08$ per ton to construct, or $\$ 30,003$. With the exception of a voyage to Auckland, New Zealand in 1870-71 and Buenos Aires in 1875, William traded almost exclusively in the North Atlantic throughout its career, carrying oil from Philadelphia to Cork or Falmouth, among other cargoes. Captain Decker virtually became a member of the Stairs family, and W.J. was the executor of his will when he died in 1881. William earned good income for its owners until 1885, when the Stairs shipping ledger shows no income earned. In its last three years of productive service, the venerable old workhorse earned a mere $\$ 12.10$ per ton, or $\$ 8,627$. It was condemned at St. Thomas in 1888 and presumably sold. ${ }^{36}$

During the decade of the 1870s, W.J. established himself as a shipowner, and he began to develop links between his shipping activities and other enterprises, the chandlery and ropeworks. He registered eight vessels, totalling 2,065 tons, during the peak decade of Nova Scotia shipbuilding. Counting two vessels built in the previous decade, his total fleet throughout much of the decade would have been about ten vessels. It included four ships, three barques, two schooners and one barquentine. This ownership pattern probably indicates an opportunistic and flexible approach to shipowning rather than being devoted to one particular type of ship or trade.

W.J. owned 32 shares of the 1,263 ton William Douglas, his second and largest vessel to date, built at Maitland in 1874 , at a cost of $\$ 62,152$. The vessel's other owners

35 NSARM, MG1, vol. 3265, folder 5, "WSS\&M Shipbuilding Costs"; Lloyd's List, 1867-81; Armour and Lackey, Sailing Ships.

36 Lloyd's List, 1870-84; "WSS\&M Shipbuilding Costs"; NSARM, MG 1, vol. 3265, folder 17, "Vessel Income, 1883-1897." 


\begin{tabular}{|c|c|c|c|c|c|c|}
\hline Vessel Name & Rig & Tonnage & Years Owned & Owner(s) & No. Shares / 64 & Tons Owned \\
\hline Stanley & b'tine & 345 & $1882-83$ & W.J. Stairs & 32 & 172.50 \\
\hline Wenona & bq'tine & 530 & $1882-83$ & $"$ & 64 & 530.00 \\
\hline Eillan Donan & b'tine & 269 & $1883-84$ & $"$ & 64 & 269.00 \\
\hline Kate Melick & bk & 759 & $1883-84$ & $"$ & 8 & 94.88 \\
\hline Osmond O'Brien & bk & 878 & $1883-94$ & $"$ & 8 & 109.75 \\
\hline Linden & bk & 913 & 1883-94 & $"$ & 2 & 28.53 \\
\hline R. Morrow & bk & 1156 & 1884-1906 & $"$ & 12 & 216.75 \\
\hline Osberga & bk & 1158 & 1884-1908 & $"$ & 16 & 289.50 \\
\hline Craigie Burn & bk & 1121 & $1885-88$ & $"$ & 8 & 140.13 \\
\hline Chas Duncan & sch & 156 & 1886 & WSS\&M & 32 & 78.00 \\
\hline \multirow[t]{2}{*}{ Avonia } & bk & 1664 & $1886-1904$ & $"$ & 4 & 104.00 \\
\hline & & & & & Total: & 2033.04 \\
\hline
\end{tabular}

Table 2: William J. Stairs Vessels, 1860s.

included the skipper, Thomas Douglas, William Douglas, his father and long-time Stairs employee, the builder, Alex Roy, his brother, Thomas Roy, and the Maitland merchants, George Frieze and Adam Roy; this relationship represented a unique marriage of Halifax capital and local enterprise. Lloyd's List picks up the ship's voyages in New Orleans in January 1876, whence it sailed to Liverpool. From Liverpool it went to Bombay and Calcutta, returning to Le Havre. In 1879 it traded North Atlantic, but the next year made another voyage to Bombay. In 1880 it languished in Leith, Scotland for three months before setting sail for Philadelphia. The vessel traded North Atlantic for the next 12 months, and then made a return voyage from New York to Havana. For the next four years, it traded between New York and India. By 1885 it was back on the North Atlantic, but spent 1886 in the Indian Ocean. It sailed back and forth between New York and Antwerp, probably carrying oil, during 1887-89, before it was sold to Norwegians in either 1889 or 1890 .

This pattern of sailings was quite typical of most Nova Scotia and Maritimes vessels. Obviously worried about flagging fortunes, W.J. began to track vessel income in 1883. That year, William Douglas earned

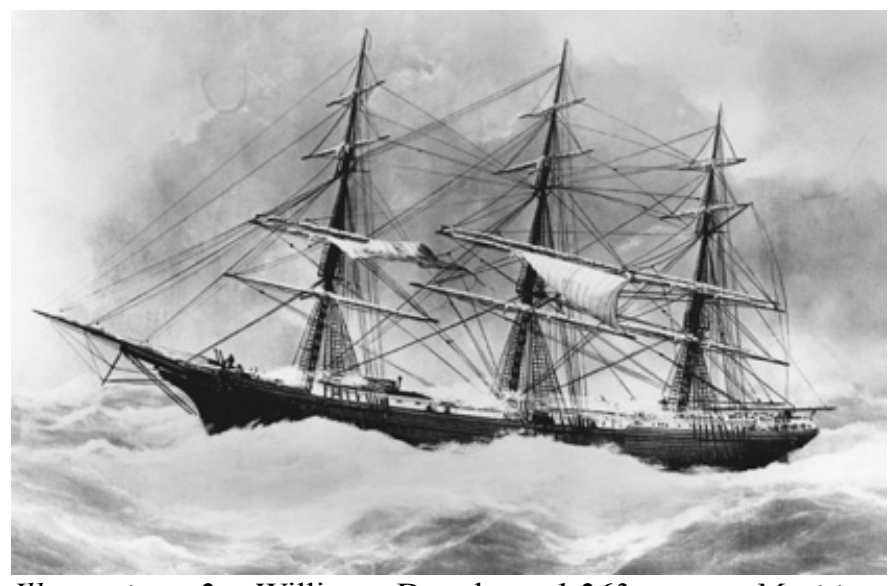

Illustration 2: William Douglas, 1,263 tons, Maritime Museum of the Atlantic. 
$\$ 15.56$ per ton, more than any other vessel in his fleet. In 1884 this amount fell to $\$ 8.18$, still the best in the fleet. In 1885 it earned a respectable $\$ 9.39$, considering competition from other sailing vessels and steamships. In 1886, after spending most of the year in the Indian Ocean, which had proven to be very profitable three years previously, the vessel only earned $\$ 1.26$ for reasons not evident. Its fortunes revived on the North Atlantic in 1887 to $\$ 7.52$, but dropped the next year to $\$ 1.24$. Its last two years were quite encouraging, earning $\$ 6.92$ and $\$ 6.97$ respectively, but income volatility and age must have been reason enough to sell in view of an offer to purchase. ${ }^{37}$

In 1877 W.J. built two large vessels, the 1,178 ton Bedford and the 1,533 ton Esther Roy. Bedford was another community venture, this time involving Colchester County interests. Its owners included James Crowe, builder, of Clifton, James Caffrey, merchant, of Truro, John Congdon, master mariner, of Great Village, James P. Crowe, master mariner, of Maitland, George Forsyth, merchant, of Halifax, and John and Dougald Alexander both of Old Barns, the former a merchant and the latter a carpenter. Bedford was ship-rigged and cost its owners $\$ 50,654$ to build. W.J. owned 16 of 64 shares and was the managing owner from 1877 to 1891 . Bedford spent the first ten years of its career trading North Atlantic, mainly between Philadelphia and Antwerp. ${ }^{38}$

On one of these voyages across the Atlantic, on a trip from New York to Antwerp while carrying a cargo of petroleum, Bedford ran into a gale and was hit by lightning, which "struck the fore-topgallant royal mast, darted along the rigging, also to the main and mizzen tops, and then from all the tops proceeded downwards along the rigging." 39 Very soon afterwards, smoke was seen rising from the fore hatch, "fire in a large ship, laden with petroleum!" ${ }^{40}$ In the captain's words, "with the greatest caution water was thrown on the cargo through the fore hatch, after which the hatches were covered with strong tarpaulin and tightly battened down." ${ }^{41}$ The smoke continued to rise and "it was evident to those on board that the fire was not extinguished, that they had...a floating volcano under them." ${ }^{42}$ A decision was made to abandon ship, but in the process of doing so, the crew noticed that the smoke had diminished. They decided to carry on to their destination, even after discovering their rudder had broken and the lightning had altered their compass readings. No attempt was made to open the hatches the rest of the voyage, for fear of admitting oxygen. "There was consequently no absolute certainty that the fire was quite extinguished." ${ }^{33}$ This incident was a good illustration of the perils of the trade, for both sailors and owners. Misfortune was never far away, nor, it seems, good luck.

The vessel subsequently made its destination and discharged its cargo safely, for

37 MHA, Certificate of Registry; ibid., Crew Agreements, 1875-88; Lloyd's List, 1876-89; "WSS\&M Shipbuilding Costs,"; "Vessel Income, 1883-1897." Lloyd's List, 1876-91; Pickford and Black papers.

39 Morning Chronicle, 22 May 1885.

40 Ibid.

41 Ibid.

42 Ibid.

43 Ibid. 
it continued in the same trade for another few years. It included a visit to its home port in November 1889, where it spent over a month loading a huge cargo of lumber and deals for London. Like most sailing ships Bedford began to find cargoes further afield, and made a lengthy voyage from London to New South Wales, and from Australia to Valparaiso, Chile. From Chile, it sailed back to Falmouth, thence to Rotterdam, New York and back to Buenos Aires. From Buenos Aires it sailed to its home port of Halifax, from where the captain set sail for the United Kingdom, where he picked up a cargo for Montevideo. It made one last trip to New York and back to Rio de Janeiro, before sailing to Barbados for orders, then to the United Kingdom where the ship was sold to Swedes. ${ }^{44}$ Bedford earned respectable revenues of $\$ 8.00$ per ton in 1883 , slipping to $\$ 5.11$ in 1884 and $\$ 4.13$ in 1885. It earned no revenue in 1886 to 1887 and marginal revenues of less than $\$ 2.00$ the next two years, before bouncing back to the $\$ 6.00$ range in 1890 to $1891 .^{45}$ These numbers serve to illustrate how volatile and unstable wooden-ship owning had become by this time.

Esther Roy was the pride of the Stairs fleet. Launched on 25 October 1877, it was built in Maitland by Frieze and Roy, at a cost of nearly $\$ 64,500$, and was among the last of its kind. Besides W.J. Stairs, who had the largest holding of 16 shares, its owners, all of whom lived in Maitland, included Thomas Roy, master mariner, Alex Roy, shipbuilder, Adam Roy, merchant, George Frieze,

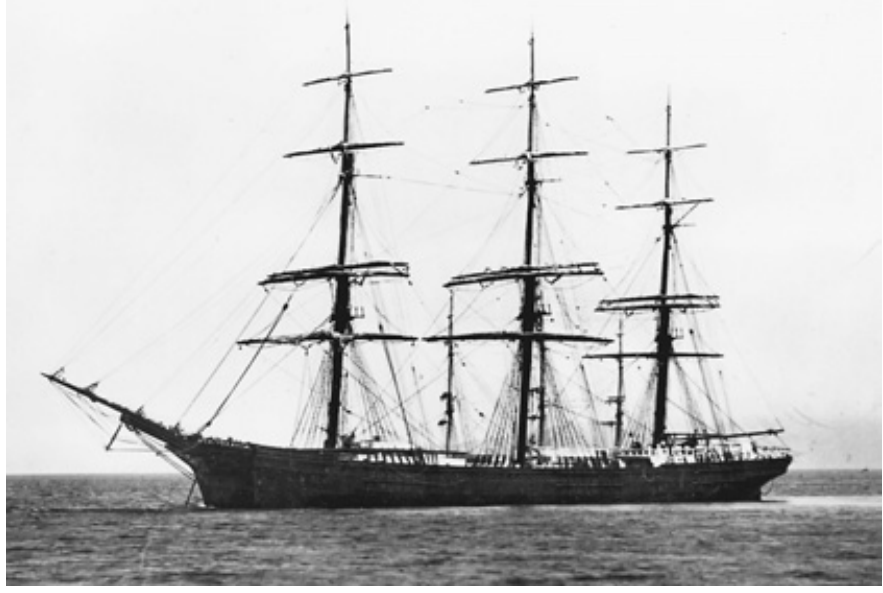

Illustration 3: Esther Roy, 1,533 tons, pride of the fleet, c. 1890, Maritime Museum of the Atlantic. merchant, Fred Frieze, blacksmith, William Douglas, master mariner, and Stephen Putnam, farmer. ${ }^{46}$ Esther Roy's first crew of 16 were mostly from Nova Scotia, but included three Scots, two Englishmen, and one Maltese. Reflecting the strict Presbyterian background of the ship's managing owner, the crew agreements very specifically stated either no grog or no spirits allowed. Rations usually included bread every day, beef and pork on alternate days, flour and peas three times a week, with tea, coffee, sugar and water daily. After the first voyage it was unusual to have any Nova Scotians on board other than the master. By its third voyage, which officially commenced in September 1879, the crew consisted of three Nova Scotians, the master, first mate, and bosun, along with three each from Sweden, Scotland, and England, two Australians, two Danes, and one each from Norway, Finland,

\footnotetext{
44 Lloyd's List.

45 "Vessel Income, 1883-1897."

46 "WSS\&M Shipbuilding Costs."
} 
Ireland and China. Wages were $\$ 18.00$ per month. There were many desertions during each voyage and an extremely high turnover, which was fairly typical for this industry because of rates of pay and general working conditions. ${ }^{47}$

After launching, Esther Roy sailed immediately to Norfolk, Virginia, in ballast, where it loaded 5,229 bales of cotton for Liverpool at a rate of $£ 2,675$. The new vessel discharged and sailed in ballast again for Philadelphia, where it loaded case oil for Liverpool. From Liverpool, it sailed for New York in ballast and loaded wheat for Antwerp. The first mate, J.H. O'Brien, noted in his log, "the same night in a heavy gale of wind both cables parted. We put on sail and ran the ship on shore, as we could not see where we were going, the weather was so thick." ${ }^{48}$ They loaded railway iron at Antwerp and once again sailed for New York. Stairs vessels were venturing further and further away from Nova Scotia. In April 1878, after a few more trips across the Atlantic, they sailed from New York to Bombay with a load of case oil. From Bombay the vessel sailed to Rangoon, which was described as "Further India," where they loaded 2,308 tons of rice for Liverpool.

They spent two more years on various voyages across the Atlantic, carrying wheat and case oil eastbound and mainly iron or general merchandise westbound, before sailing from the River Tyne in August 1881, with a load of coal for San Francisco, making the passage in 112 days. From San Francisco, after recruiting a virtually new crew, they sailed two months later for Cobh, Ireland, with a cargo of wheat. They made two more trips across the Atlantic before sailing from Cardiff in 1884 with a cargo of coal for Montevideo. From Montevideo the vessel sailed for Barbados, an important port for obtaining orders for vessels heading for or coming to, the U.S. Gulf, the Caribbean or South America. After Barbados, Esther Roy sailed from New Orleans with 3,000 bales of cotton to Le Havre, France, for which the owners were paid the incredible sum of $\$ 17,700$.

From Le Havre they sailed for Shelburne and Parrsboro, NS, the first time the vessel had visited Nova Scotia since its launch seven years earlier. They loaded deals and sailed for Liverpool. From Liverpool in June 1885 Esther Roy was chartered to Rio with a load of coal. After a 48-day voyage, they arrived in Rio and departed again for Barbados, where they received orders to proceed to New York to load case oil for Calcutta. After a 116-day voyage, the vessel arrived in Calcutta and loaded general cargo of rattan, etc., at $\$ 4.50$ per each of 1,400 tons, before returning to New York. By 1888 , the vessel was back in the North Atlantic, carrying oil eastbound and wire rod westbound. Late that year there was another trip from Cardiff to Montevideo, and the next year a another run from New York to Calcutta.

47 MHA, Crew Agreements, 1877-96; Colin Howell and Richard Twomey, eds., Jack Tar in History: Essays in the History of Maritime Life and Labour (Fredericton, 1991); Richard Henry Dana, Two Years before the Mast (reprint; New York, 1964). See also Lewis R. Fischer, "A Dereliction of Duty: The Problem of Desertion on Nineteenth Century Sailing Vessels," in Rosemary Ommer and Gerry Panting, eds., Working Men Who Got Wet (St. John's, 1980), 51-70. 
In early 1890 Esther Roy was chartered from New York to Hong Kong with 56,299 cases of oil, at $\$ 16,608$. It went aground at a place called Brothers in the Strait of Malacca, after the master "became deranged." 49 The crew jettisoned 3,500 cases and proceeded to Batavia with the hull leaking badly. The vessel was subsequently chartered from Java to Montreal with a cargo of sugar.

As steamships began to make more incursions into sailing trades and there was more competition from sailing vessels, Esther Roy had to sail much further afield during the last five years under the Stairs house flag. In November 1891, after carrying coal from Cardiff to Rio for $\$ 1,790$, it sailed in ballast from Rio to Java to load sugar for Montreal. In 1892, it sailed once again from Montreal to Buenos Aires for $\$ 9,152$. In 1893, the vessel made a couple of trips across the Atlantic between Nova Scotia and Falmouth carrying deals. In 1894, it sailed from New York to London early in the year, and then sailed for Montevideo once again. From Montevideo they sailed in ballast all the way to Newcastle, Australia to load coal for Ilvilo, Japan. In 1895, Esther Roy traded between Newcastle and Japan, before securing a charter of general cargo from Manila to Liverpool. When they returned to Liverpool the vessel was sold to foreigners, probably Norwegians, having spent almost twenty years in the Stairs fleet. Earnings were a paltry $\$ 1.45$ per ton during its last year of employ, compared with a peak of $\$ 12.05$ in $1883 .^{50}$ This probably reflected the age of the vessel and market conditions for sailing ships. The Stairs were also engaged in other landward pursuits by this time. ${ }^{51}$

\begin{tabular}{|l|l|l|l|c|l|r|}
\hline Vessel Name & Rig & Tonnage & $\begin{array}{l}\text { Years } \\
\text { Owned }\end{array}$ & Owner(s) & $\begin{array}{l}\text { No. } \\
\text { Shares / 64 }\end{array}$ & $\begin{array}{l}\text { Tons } \\
\text { Owned }\end{array}$ \\
\hline Ragnar & ship & 927 & $1871-97$ & W.J. Stairs & 8 & 114.13 \\
\hline William Douglas & ship & 1263 & $1875-89$ & $n$ & 32 & 631.50 \\
\hline Warrior & sch & 102 & $1875-05-01$ & $n$ & 16 & 25.50 \\
\hline Elba & b'tine & 308 & $1877-82$ & $n$ & 64 & 308.00 \\
\hline Terra Nova & sch & 218 & $1877-85$ & $n$ & 32 & 109.00 \\
\hline Bedford & ship & 1178 & $1877-91$ & $n$ & 16 & 294.50 \\
\hline Esther Roy & ship & 1533 & $1877-96$ & $n$ & 16 & 383.25 \\
\hline W.J. Stairs & bk & 1065 & $1879-82$ & $n$ & 12 & 199.69 \\
\hline & & & & & & Total: \\
\hline
\end{tabular}

Table 3: William J. Stairs Vessels, 1870s.

W.J. Stairs acquired his 11/64 interest in Linden and thereafter became the vessel's managing owner in 1886, in lieu of the owners paying their chandlery bills. These bills were related to damages suffered shortly after the vessel was launched in

49 Ibid.

50 Lloyd's List; NSARM MG1, vol. 3250, folder 7, "Esther Roy log book"; "Vessel Income, 1883-1897”; J.H. O’Brien, "autobiography."

51 Frost, Merchant Princes. 
$1881 .{ }^{52}$ It was a three-masted barque of 938 tons, built by James Crowe in Clifton, NS. Linden was his second venture with investors in Colchester County, including the Crowe and the Dickie families. After W.J. acquired control of the vessel, earnings continued to fall, from $\$ 6.78$ in 1885 , to $\$ 4.47$ in $1886, \$ 3.14$ in 1887 and $\$ 0.91$ in 1888. They recovered nicely the next three years to $\$ 7.04, \$ 7.62$ and $\$ 8.18$ respectively, before the ship was sold. The vessel's pattern of voyages was very similar to others at this time. It traded North Atlantic until 1888, when it made its first voyage from the U.K. to South America, returning to New York, and then making another trip to Buenos Aires in 1889. It was sold to Norwegians in 1892; they traded the vessel between Savannah and Liverpool, after which it began to sail further afield in search of cargoes, to Buenos Aires, Valparaiso, and, in 1894, India. ${ }^{53}$

R. Morrow was a three masted barque, of 1,156 tons, built at Maitland in 1884, by Frieze and Roy. Built at a cost of $\$ 36.75$ per ton, or $\$ 42,483$, its owners included W.J., who owned 12 shares, Alex Roy, shipbuilder, Thomas Roy, master mariner, J.H. O'Brien, the ship's master, and George Frieze, merchant, who each owned eight shares, Adam Roy, merchant, who owned five, James Roy, clerk, Edwin Roy, shipbuilder, and William Roy, clerk, who each owned four shares, Robert Currie, clerk, and George Currie, joiner, who owned two shares, and John Currie, a carpenter who owned one share. ${ }^{54}$ By this time, the shipbuilders of Maitland had built at least 197 vessels since 1843. They would build another twenty before the industry expired in 1894. At the firm's peak it employed over 1,000 men every summer. ${ }^{55}$

\section{The last days of wood, wind and sail, 1885-1925}

By the mid-1880s, the waning days of wood, wind and sail confronted W.J. Stairs with a dilemma. Craigie Burn, a three-masted barque of 1,121 tons was built in 1885 by A.A. McDougall of Maitland, John N. Welling, a master mariner from Amherst, and W.J. It had a rather chequered career. Since W.J. only owned 8 of 64 shares it is likely he made the investment to ensure it was outfitted by WSS\&M. Voyage data are only available from 1887 onwards, when Craigie Burn was in Montevideo. That year it sailed from Montevideo to Iquique, Chile, to Portland, Maine, and from there to Antwerp. The next year the vessel made another two trips to South America. It was condemned and sold to foreign interests at Montevideo in early 1889, but repurchased in Cardiff as Thomas Faulkner in 1890. W.J. appears to have been the managing owner from 1887 to 1888 and 1894 to 1895 . In 1894, the vessel made sixteen round trip voyages between Bordeaux,

52 NSARM, MG 1, vol. 3265, folder 7, 12 October 1886.

53 MHA, Vessel and Owners Registry; ACSP Voyage Data; Lloyd's List, 1883-94; "Vessel Income, 1883-1897."

54 MHA, Certificate of British Registry; "WSS\&M Shipbuilding Costs."

55 Maitland very much deserves a study of its own. Hawkins' study does not do it justice. See Hawkins, Captains, Mansions and Millionaires:The Remarkable Story of Maitland, Nova Scotia (Hantsport, NS, 1996); Halifax Herald, 8 August 1899, 17 May 1902; Truro Daily News, 17 September 1903; Morning Chronicle, 30 June 1927; Chronicle-Herald (Halifax), 8 February 1964. 
France and Newport, Rhode Island. The next year it made a round trip from Buenos Aires to the U.K. In 1887-88 earnings were $\$ 2.55$ and $\$ 6.61$, while the next period saw earnings of $\$ 2.13$ and $\$ 4.22$, respectively, which were hardly encouraging. ${ }^{56}$

Avonia was the last and largest new ship acquired by W.J., and even though WSS\&M would acquire a number of vessels during the decade, it represents their last gasp in the age of sail. It was a three-masted barque of 1,664 registered tons, built at Horton in 1886 at a cost of $\$ 35.00$ per ton, or $\$ 58,240$. WSS\&M bought four shares, most likely performed the outfitting and became managing owners. Except for the latter two reasons, Avonia was, given the timing, a curious investment. The vessel was able to find cargoes in the usual places, but much less frequently and remuneratively than its older sister ships. W.J. Stairs' income ledger showed zero net income for Avonia from 1886 to 1896 , so it is unlikely it ever paid back its owners' investment; still, the vessel plied the high seas until $1904 .{ }^{57}$

\begin{tabular}{|c|c|c|c|c|c|c|}
\hline Vessel Name & Rig & Tonnage & Years Owned & Owner(s) & $\begin{array}{l}\text { No. } \\
\text { Shares / } 64\end{array}$ & $\begin{array}{l}\text { Tons } \\
\text { Owned }\end{array}$ \\
\hline Stanley & b'tine & 345 & $1882-83$ & W.J. Stairs & 32 & 172.50 \\
\hline Wenona & bq'tine & 530 & $1882-83$ & $"$ & 64 & 530.00 \\
\hline Eillan Donan & b'tine & 269 & $1883-84$ & $"$ & 64 & 269.00 \\
\hline Kate Melick & bk & 759 & $1883-84$ & $"$ & 8 & 94.88 \\
\hline Osmond O'Brien & bk & 878 & $1883-94$ & $"$ & 8 & 109.75 \\
\hline Linden & bk & 913 & $1883-94$ & $"$ & 2 & 28.53 \\
\hline R. Morrow & bk & 1156 & 1884-1906 & $"$ & 12 & 216.75 \\
\hline Osberga & bk & 1158 & 1884-1908 & $"$ & 16 & 289.50 \\
\hline Craigie Burn & bk & 1121 & $1885-88$ & $"$ & 8 & 140.13 \\
\hline Chas Duncan & sch & 156 & 1886 & WSS\&M & 32 & 78.00 \\
\hline \multirow[t]{2}{*}{ Avonia } & bk & 1664 & 1886-1904 & $"$ & 4 & 104.00 \\
\hline & & & & & Total: & 2033.04 \\
\hline
\end{tabular}

Table 4: William J. Stairs Vessels, 1880s.

Savona was a large three-masted ship-rigged vessel of 1,649 tons, built in 1891 by W.P. Cameron in South Maitland for Martin Dickie, shipowner, Harriet Dickie, widow, of Truro and Frederick Bullock, merchant, of Halifax. Cameron sold off most of his shares in 1892 to a number of investors, who may have been creditors. They included William J.'s brother-in-law Geoffrey Morrow, of WSS\&M, Charles Putnam, an insurance agent in Maitland, Joseph Snook, a merchant from Truro, and Wiley Smith, a merchant

56 MHA, Certificate of British Registry; Lloyd's List, 1887-88 and 1894-95; Lloyd's Register, 1891; "Vessel Income, 1883-1897."

57 MHA, Vessel and Owners Registry; Lloyd's List, 1886-94; "Vessel Income, 1883-1897"; "WSS\&M Shipbuilding Costs." 
from Halifax. Morrow's two shares in Savona were later transferred to WSS\&M after it was incorporated and WSS\&M probably became managing owners after 1892. From 1892 onwards, Savona's cargoes were few and far between. In late 1892, the vessel sailed from Calcutta to Boston with a load of general cargo at $\$ 5.00$ per ton, about half the former rate. From Boston it sailed to Buenos Aires, from where it sailed to Newcastle, for a load of coal to Manila. From Manila they sailed to Delaware for orders, and then proceeded to New York, where they were chartered to Australia for a mere $£ 1,950$, which would hardly have covered costs. From Sydney, Savona sailed to the United Kingdom with a cargo of shale. It was subsequently chartered to Manila sometime in 1896, where hemp was loaded for Boston. After returning to the United States, it was chartered from Philadelphia to Hiojo, Japan with a load of case oil. The vessel returned to the U.S. with another cargo of hemp at $\$ 3.75$ per bundle, $\$ 0.75$ less than the rate which $R$. Morrow, Osberga and Avonia were obtaining. Savona was involved in a lengthy case in the British Admiralty Court during the first six months of 1900, in which it was alleged that it was in violation of its charter party agreement for having put into Falmouth to make repairs, after setting sail from Cardiff to Cape Town with a cargo of coal. The cargo had to be discharged because it had shifted and got wet. The court found in favour of the owners, and the ship eventually sailed for Algoa Bay, near Port Elizabeth, South Africa. In 1901, it made a voyage from Sydney to Rotterdam, and then another from Cardiff to Cape Town. WSS\&M sold their share in Savona to Martin Dickie in 1906, when he became the sole owner. By this time the vessel went through dozens of owners. Savona was stranded at Cobh Islands, County Cork, in January 1909 and declared a total loss. ${ }^{58}$ The family was also in transition at this time, as William J.'s son John F., died in 1904 at age 56, and William J. died in 1906. Another son, George, died in 1908 and the new generation of Stairs managers were less interested in vessels than they were keeping the family firm alive.

After Savona, the Stairs family or WSS\&M may have owned another eight vessels, but details are difficult to confirm. One of them, Kathleen, was a barquentine, of 325 tons owned briefly from 1890 to $1894 .{ }^{59}$ They appear to have owned a number of fishing schooners after the turn of the century, which may have been more related to the chandlery business than with ship owning. ${ }^{60}$ Lord of Avon, 325 tons, built in 1901, and Lady of Avon, 417 tons, built the next year, were both large four-masted schooners, which WSS\&M acquired in 1906. Lord of Avon's career ended in 1913 on a passage from Pensacola, Florida to Cienfuegos, Cuba with a cargo of lumber when the schooner was wrecked in a storm. Lady of Avon suffered a similar fate the next year, on a voyage from Annapolis, Nova Scotia to Cienfuegos. ${ }^{61}$ Village Belle, a 99-ton schooner built in 1907,

58 MHA, Certificate of British Registry; Lloyd's List, 1894-97; Lloyd's Register, 1896-97; "Vessel Income, 1883-1897"; Halifax Herald, 8 September 1900; F.W. Wallace, Wooden Ships and Iron Men (Boston, 1937), 318.

59 Lloyd's Register, 1893-94; Lloyd's List, 1883-94.

60 These may have included Lord of Avon, Lady of Avon, Con Rein, and Joyce M. Smith.

61 The MHA were unable to confirm WSS\&M's purchase of both these vessels. However, company documents suggest they owned the vessels, at least for a short while. NSARM, 
was originally intended for fishing. It was later fitted out to do exploration work in Hudson's Bay. ${ }^{62}$ Benjamin C. Smith was another fishing schooner, built at La Have in 1911, in which WSS\&M owned four shares. ${ }^{63}$

During the First World War, the company's managers were not unmindful of short-term opportunities. In 1910, Gavin Stairs bought Calburga at a sheriff's auction for $\$ 4,500$, and sold it in 1915 for $\$ 18,000$, after a number of very lucrative trips running the German submarine blockade into Ireland and the west coast of Britain. ${ }^{64}$ The last vessel purchased by WSS\&M was the fishing schooner Joyce M. Smith, built at Salmon River, Nova Scotia in 1920. It went missing in a storm in 1927, after which its register was closed. ${ }^{65}$ This was the family's swan song as ship owners, but the family firm kept going until 1973.

Revenues from shipping declined from $\$ 7.74$ per ton in 1883 to $\$ 2.27$ per ton in 1886. They recovered briefly to $\$ 7.16$ per ton in 1890 , but by 1896 were only $\$ 0.75 .{ }^{66}$ As we have seen, this pushed the wooden sailing ships of the Stairs and other Maritime owners into the so-called cross-trades of the Far East and South America, or out of shipping altogether. WSS\&M's shipping agency or consignment business was reduced to a trickle by the end of the 1880 s, to the point where they were only handling schooners arriving with sugar and rum from the West Indies, as well as the occasional shipment of hemp for the ropeworks. ${ }^{67}$ The value of ships in the company ledger was reduced from a peak of $\$ 103,190$ or 15 percent of the company's assets in 1887 , to $\$ 6,190$ or 1 percent of the company's assets in $1903 .{ }^{68}$ By now, the firm had decided to focus on hardware and plumbing supplies. It would later venture into the very lucrative heavy construction equipment business.

MG1, vol. 3277, folder 10; John P. Parker, Sails of the Maritimes, The Story of the Three and Four Masted Cargo Schooners of Atlantic Canada, 1859-1929 (Toronto, 1960), 96, 102. NSARM, MG1, vol. 3260, folder 12; Maritime Merchant, 15 October 1931; Sydney Post, 1 January 1934, MHA, Certificate of British Registry; Lloyd's List, 1908.

63 NSARM, MG1, vol. 3272, folder 2; MHA, Certificate of British Registry; Lloyd's Register, 1918.

64 NSARM, MG1, vol. 3274, folder 9; vol. 3268, folder 4; MHA, Certificate of British Registry. Calburga was originally listed as owned by Thomas Douglas, a Stairs employee and master mariner. Lloyd's Register, 1890.

65 NSARM, MG1, vol. 3258, folder 11; MHA, Certificate of British Registry; Lloyd's Register, 1925.

66 "Vessel Income. 1883-1897." The classic work on shipping rates is L. Isserlis, "Tramp Shipping Cargoes and Freights," Journal of the Royal Statistical Society, New Series, 101 (1938), 53-134; this work has been updated by Lewis R. Fischer and Helge Nordvik, "Maritime Transport and the Integration of the North Atlantic Economy, 1850-1914," The Emergence of a World Economy, 1500-1914, W. Fischer, R.M. McInnis and J. Schneider, eds. (Wiesbaden, 1986), 519-44. See also, C. Knick Harley, "Ocean Freight Rates and Productivity, 1740-1913," Journal of Economic History 48 (December, 1988), 851-876. 


\begin{tabular}{|l|l|l|l|l|l|l|l|l|l|}
\hline Vessel & owned & tons & 1883 & 1884 & 1885 & 1886 & 1887 & 1888 & 1889 \\
\hline Linden & & & $\$ 10.54$ & $\$ 7.89$ & $\$ 6.78$ & $\$ 4.47$ & $\$ 3.41$ & $\$ 0.91$ & $\$ 7.04$ \\
\hline William & $1869-88$ & 713 & $\$ 3.60$ & $\$ 6.14$ & $\$ 2.36$ & $\$ 0.00$ & $\$ 0.00$ & $\$ 0.00$ & $\$ 0.00$ \\
\hline Osmond O'Brien & & & $\$ 3.07$ & $\$ 5.41$ & $\$ 4.13$ & $\$ 0.00$ & $\$ 0.00$ & $\$ 1.96$ & $\$ 1.39$ \\
\hline Kate Mettick & & & $\$ 9.14$ & $(\$ 0.80)$ & & & & & \\
\hline Bedford & $1877-91$ & 1178 & $\$ 8.00$ & $\$ 5.11$ & $\$ 4.13$ & $\$ 0.00$ & $\$ 0.00$ & $\$ 1.96$ & $\$ 1.39$ \\
\hline Wm Douglas & $1875-89$ & 1263 & $\$ 15.56$ & $\$ 8.18$ & $\$ 9.39$ & $\$ 1.26$ & $\$ 7.52$ & $\$ 1.24$ & $\$ 6.92$ \\
\hline Ragnar & $1871-97$ & 927 & $\$ 0.00$ & $\$ 7.90$ & $\$ 8.31$ & $\$ 1.05$ & $\$ 0.00$ & $\$ 2.00$ & $\$ 1.04$ \\
\hline Esther Roy & $1877-96$ & 1533 & $\$ 12.05$ & $\$ 4.45$ & $\$ 9.76$ & $\$ 3.05$ & $\$ 4.81$ & $\$ 6.29$ & $\$ 3.55$ \\
\hline Chas Duncan & & & & & & & $\$ 4.09$ & & \\
\hline Osberga & $1884-1908$ & 1158 & & & & $\$ 4.82$ & $\$ 5.17$ & $\$ 1.75$ & $\$ 4.36$ \\
\hline R.Morrow & $1884-1906$ & 1156 & & & & $\$ 1.86$ & $\$ 6.74$ & $\$ 5.16$ & $\$ 12.94$ \\
\hline Craigie Burn & & & & & & & $\$ 2.55$ & $\$ 6.61$ & \\
\hline Savona & & 1649 & & & & & & $\$ 6.38$ & $\$ 6.68$ \\
\hline Avonia & & 1664 & & & & & & & \\
\hline Kathleen & & & & & & & & & \\
\hline Average & & & $\$ 7.74$ & $\$ 5.53$ & $\$ 6.76$ & $\$ 2.27$ & $\$ 3.61$ & $\$ 3.11$ & $\$ 6.13$ \\
\hline
\end{tabular}

Table 5: Stairs Vessel Income (continues opposite.)

All told, the Stairs family had owned 44 sailing ships, totalling 6,515 tons over the period 1826 to 1926. If the vessels owned by W.J.'s brother (John Stairs), who had left the firm in 1853, and Robert Morrow (W.J.'s brother-in-law), who had replaced him are included, the family's total fleet over a century had amounted to 63 ships, totalling 12,160 tons. Since John Stairs was, in effect, on his own after 1853, it is probably more accurate to express the family fleet in terms of those individuals associated with WSS\&M. By this measure, the total fleet was a significant 48 vessels, or 9,547 tons. ${ }^{69}$ The fleet was most important in the 1830s, 1870s and 1880s. What is most surprising is their lack of participation, except for two vessels owned by Robert Morrow, and one small schooner by William and W.J., in the boom years of the 1850s, and their persistence, against what must have seemed redoubtable odds, in the 1880s and 1890s. Both phenomena are probably explained by their core business, which was, after all, chandlery. They may have had enough demands on their time ministering to their own customers during the 1850 s not to be bothered with shipowning. WSS\&M's sales figures give some credence to this assertion. ${ }^{70}$ In the $1880 \mathrm{~s}$ and 1890 s, their persistence in what was a dying industry was probably related to self-preservation. Investing in ships brought in business to WSS\&M and their ropeworks in Dartmouth. Managing them helped protect their investment, while earning some revenue in the process.

69 MHA, Vessel and Owners Registry. Calculations by the author.

70 NSARM, MG1, vol. 3277, folder 2, "WSS\&M Sales and Profits, 1842-1953." 


\begin{tabular}{|l|l|l|l|l|l|l|l|l|l|}
\hline 1890 & 1891 & 1892 & 1893 & 1894 & 1895 & 1896 & Total / ton & Total earnings & Building cost \\
\hline$\$ 7.62$ & $\$ 8.18$ & $\$ 0.00$ & $\$ 0.00$ & $\$ 0.00$ & & & $\$ 49.78$ & & $\$ 31,042.00$ \\
\hline & & & & & & & $\$ 12.10$ & $\$ 8,627.00$ & $\$ 30,003.04$ \\
\hline$\$ 5.57$ & $\$ 5.92$ & $\$ 6.33$ & $\$ 0.00$ & $\$ 0.00$ & & & $\$ 33.78$ & & \\
\hline & & & & & & & $\$ 8.34$ & & \\
\hline$\$ 5.57$ & $\$ 5.92$ & $\$ 6.33$ & $\$ 0.00$ & $\$ 0.00$ & & & $\$ 38.41$ & $\$ 45,246.00$ & $\$ 50,310.00$ \\
\hline$\$ 6.67$ & $\$ 0.00$ & $\$ 0.00$ & $\$ 0.00$ & $\$ 0.00$ & & & $\$ 56.74$ & $\$ 71,662.00$ & $\$ 62,152.23$ \\
\hline & & & & & & & $\$ 20.03$ & $\$ 18,567.00$ & $\$ 42,957.00$ \\
\hline$\$ 4.85$ & $\$ 3.79$ & $\$ 3.63$ & $\$ 4.42$ & $\$ 1.45$ & $\$ 0.00$ & sold & $\$ 62.10$ & $\$ 95,199.00$ & $* \$ 53,655.00$ \\
\hline & & & & & & & $\$ 4.09$ & & \\
\hline$\$ 15.00$ & $\$ 4.03$ & $\$ 5.49$ & $\$ 5.04$ & $\$ 1.94$ & $\$ 3.16$ & & $\$ 50.76$ & $\$ 58,780.00$ & $\$ 42,483.00$ \\
\hline$\$ 0.00$ & $\$ 7.62$ & $\$ 6.12$ & $\$ 0.00$ & $\$ 4.19$ & $\$ 6.28$ & $\$ 1.04$ & $\$ 51.95$ & $\$ 60,054.00$ & $\$ 41,477.00$ \\
\hline & & & & $\$ 2.13$ & $\$ 4.22$ & & $\$ 15.51$ & $\$ 25,575.00$ & $\$ 52,619.59$ \\
\hline$\$ 10.28$ & $\$ 10.69$ & $\$ 2.40$ & $\$ 2.51$ & $\$ 2.36$ & $\$ 4.29$ & $\$ 1.94$ & $\$ 47.53$ & $\$ 79,089.00$ & $\$ 58,240.00$ \\
\hline$\$ 0.00$ & $\$ 0.00$ & $\$ 0.00$ & $\$ 0.00$ & $\$ 0.00$ & & & & & \\
\hline & & & & & & & & & \\
\hline$\$ 7.16$ & $\$ 5.73$ & $\$ 3.99$ & $\$ 2.39$ & $\$ 2.41$ & $\$ 3.59$ & $\$ 0.75$ & & & \\
\hline
\end{tabular}

\section{Flirting with steam}

By 1870 , steam had begun to usurp sail on the British market. The peak of wooden shipbuilding in the Maritimes was in 1878, when vessels totalling over 90,000 tons were built. ${ }^{71}$ As was seen with the Stairs fleet, and typical of Halifax-owned vessels, sailing ships were pushed out of the Atlantic by steamships in the 1880s, into the longer cross-trades of South America, South Africa and the Far East. This trend had happened earlier with other Maritime fleets. W.J. started his vessel income ledger in 1883, and the earnings declined from that point onwards. Stairs was fully aware of the decline in business.

The Stairs family adjusted to the new reality. While W.J. Stairs kept a steady hand on the tiller, his son John F. began as early as 1883 to agitate for the establishment of a fast line of Atlantic steamers to sail between Halifax and the United Kingdom. Halifax had been without a regular, high quality transatlantic service since the withdrawal of the Cunard Line in 1867, having had to make do with the much slower and inferior service of the Allan Line and the Dominion Line. It was felt that Halifax was losing ground economically to Boston, New York and Montreal without a fast line. It was argued, and still is, that passengers and cargo discharged in Halifax by a fast stamer would arrive in Montreal before the same vessel even docked in New York.

John F. Stairs and several prominent Halifax merchants and shipowners established the Halifax Steam Navigation Co. Ltd. in 1883. The intention was to operate

71 Sager, Maritime Capital, 95. 
four vessels between Halifax, Saint John and London, on a fortnightly schedule. The company was capitalized at $\$ 200,000$ in 2,000 shares of $\$ 100$ each, and had the power "to own, build, acquire, buy, sell and charter steamships, ships and vessels of all kinds." 72 Its provisional directors included John F. Stairs, Thomas E. Kenny, William Roche, E.P. Archibald, William Gossip, Josiah Wood and C. Silver. ${ }^{73}$ Operations started in August 1883, with the first sailing of Sicily, a 1,078 ton iron screw steamer chartered from D. McIver \& Co., one of the owners of Cunard Line. ${ }^{74}$ It was joined or replaced in October by the 2,090 ton Juliet which sailed from London to Halifax, Saint John and Boston. Accommodation was provided for 10 first-class and 70 steerage passengers. The 1,581 ton Widdrington was chartered by the company in November 1883, and sailed for Halifax and Boston. Juliet made a second voyage from London to Halifax, Saint John and Boston on 7 December, and Widdrington sailed again on 5 January 1884.

No further sailings took place after this, although the company continued to advertise for another two to three months. Juliet was sold and Widdrington returned to its owners. ${ }^{75}$ Evidently, the venture incurred heavy losses the first year, as WSS\&M wrote off $\$ 15,000$ invested by John F. in $1884 .{ }^{76}$ This setback did not discourage him, however.

As the fast line was not commercially viable on its own, the directors applied for a Dominion government subsidy of $\$ 25,000$ per annum. ${ }^{77}$ The issue was debated in the House of Commons, and John F. Stairs carried on a lengthy correspondence with a succession of prime ministers and ministers of finance. In 1885 the company re-emerged when it bought the 1,779 ton Damara, which was advertised to sail on 7 March on its maiden voyage from Glasgow and Swansea for Halifax and Baltimore. A sister ship, the 1,789 ton Ulunda, sailed from its builders in Glasgow for Quebec and Montreal in April. Both ships were managed by partner Josiah Wood. The newly reconstituted service incorporated a new route structure: Swansea, Halifax, Baltimore, London and LeHavre. By 1886 the company ran into financial difficulties again, and was unable to make outstanding payments on the vessels. The vessels were taken over by Christopher Furness, among the founders of Furness Line, who continued the service in partnership with Halifax Steam Navigation Co. on the London-Halifax-Saint John route. Ulunda was stranded on the Canadian coast near Halifax in 1890, but was refloated and sold to another Stairs investment, Canada Newfoundland Steamship Co., running between Liverpool, St. John's and Halifax. Damara continued in service for some years, and

72 Statutes of Canada, "An Act to Incorporate the Halifax Steam Navigation Company, Ltd.," 19 April 1884; Kenny was to be John F. Stairs' Conservative running mate in 1887, and president of the Merchants' Bank of Halifax, later the Royal Bank of Canada. Ibid.

Monetary Times, 3 August 1883, 120, 10 August 1883, 147; Morning Chronicle, 5, 14, 18, 19, 20 September 1883, Halifax Herald, 18, 20 September 1883; NSARM, MG7, vol. 43, Pickford and Black papers, Ships Registers.

"Halifax Steam Navigation Company Ltd.," in N.R.P. Bonsor, North Atlantic Seaway, vol. 3 (Cambridge, U.K., 1979), 1155-57.

NSARM, MG1, vol. 3277, folder 9, ledger.

Monetary Times, 3 August 1883, 120, Bonsor, North Atlantic Seaway, 3: 1155-57. 


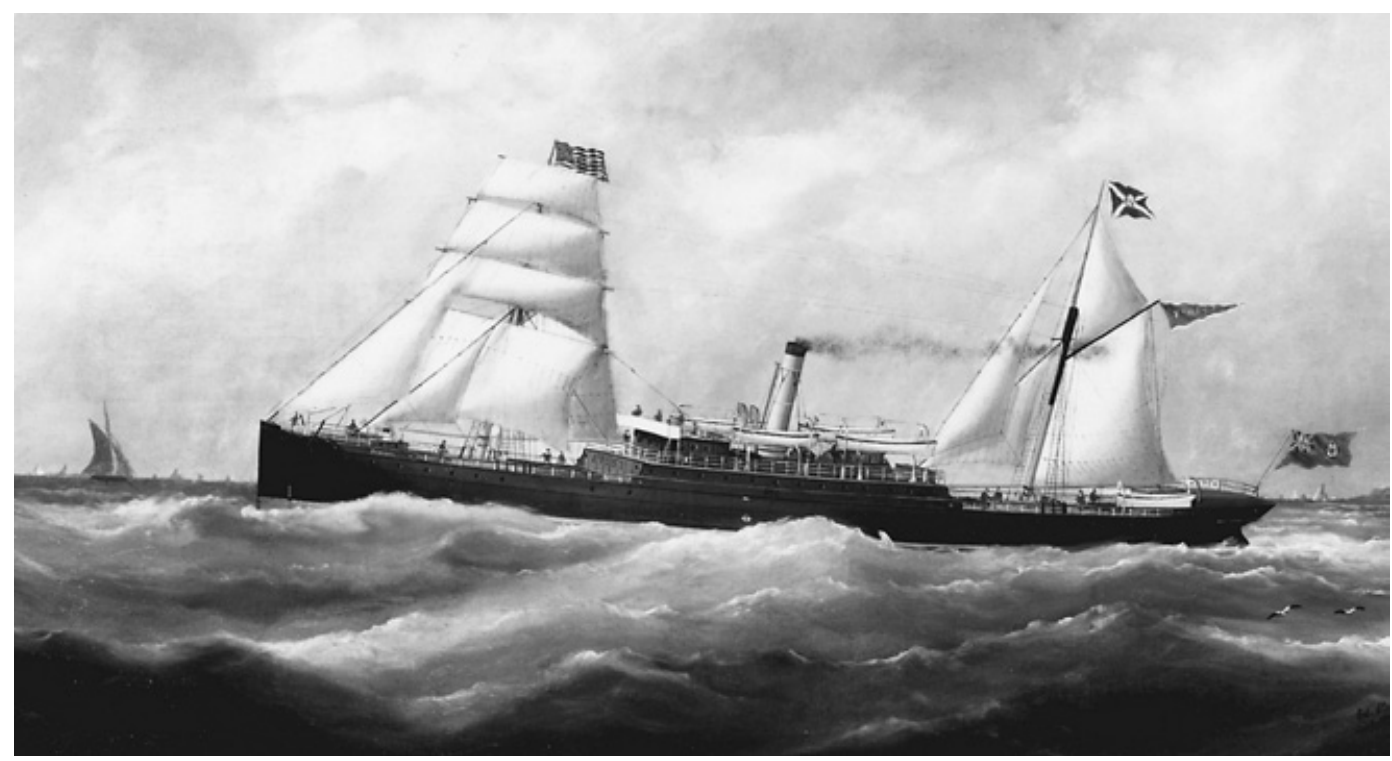

Illustration 4: S.S. Damara, Halifax Steam Navigation Company, Maritime Museum of the Atlantic.

Ulunda was replaced by another Furness ship, Halifax City. ${ }^{78}$ Having risked their own money on the venture, and received a paltry subsidy from the Canadian government, it must have been irksome to John F. Stairs and his Halifax colleagues when, in 1891, the Allan Line was allowed to carry the Canadian mails on a subsidized service via Portland, Maine. $^{79}$

The Stairs were involved in other steam-related ventures. In 1886, the Halifax Steam Boat Company went out of business and was replaced by the Halifax and Dartmouth Steam Ferry Company (HDSC), in which they held two shares. The HDSC immediately ordered a new ferry from Burrill-Johnson Iron Company in Yarmouth. Dartmouth was a double-ended, side wheel ferry steamer, 140 feet length overall, a beam of 28 feet 8 inches, with two passenger saloons. It was soon joined by Annex 2, purchased in New York. ${ }^{80}$

In 1900 WSS\&M briefly acquired the 85 -ton steam/sail vessel Pekin when its builder and prospective owner defaulted on his current account. ${ }^{81}$ In 1902, the Halifax, and Canso Steamship Company incorporated to operate a steamship service between Halifax, Canso and intermediate ports. G.S. Campbell of Halifax was the president of the company, which had a nominal capital of $\$ 50,000$, and WSS\&M were investors in it and what may have been a related company, the Halifax and Cape Breton Steamship Co. The

78 "Furness Line," in ibid.,1020-23.

79 Allan Jeffrey Wright, "“The Method of Friendly Approach,': Portland, Maine, as Canada's Winter Port" (MA thesis, University of New Brunswick, 1976).

80 Joan and Lewis Payzant, Like a Weaver's Shuttle.

81 MHA, Vessel and Owners Registry; ibid., Certificate of British Registry. 
Canso service owned two vessels, Strathcona and Scotia. Strathcona was built at Port Clyde, near Glasgow, in 1903, and blew up in 1906. Scotia was built in 1907 in Mahone Bay, and operated until $1921 .^{82}$

WSS\&M, through its controlling interest in Nova Scotia Steel and Coal Co. (NSSC), and W.J. and John F. Stairs personally, owned stakes in at least three NSSC steamships: Wasis, Wobun and Urania. Wasis was a steam/sail vessel of 480 tons built in the U.K. in 1883. NSSC may have owned it from 1898 to 1915, but at least from some time in the period 1902-05. It was utilized in transporting coal from Cape Breton and Pictou to Halifax, Quebec City and Boston, and after NSSC's purchase of the Bell Island iron ore deposit, iron ore from Newfoundland to Sydney and New Glasgow. Wobun was a much larger vessel of 1,551 tons, acquired by NSSC in 1902 and owned until 1912. Wobun carried coal from Sydney to markets in Quebec, Savannah, Norfolk, New York, and later in its career, the U.K. and France. Urania may have been a sister ship to either Wasis or Wobun, which was also acquired in $1902 .{ }^{83}$

In the early part of the twentieth century, John F. Stairs attempted to establish a steel shipbuilding industry with partners Swan Hunter Shipbuilders of Newcastle-uponTyne, the second largest such enterprise in the world at the time. George B. Hunter was convinced by John F. Stairs' vision of a fast line of steamers to connect Europe and North America, and was prepared to put up one half the money required to establish the venture, either in Halifax or across the harbour in Dartmouth. Unfortunately, the venture was stillborn, as Stairs died at the comparatively young age of 56, when in Toronto attempting to finance a new bank and his steel-making enterprise. Stairs' local partners carried on but Hunter gave up his quest in $1908 .^{84}$

Shipowning in Maritime Canada never really recovered from the decline in the 1880 s and 1890 s, as evidenced by the Stairs' experience. As Fischer and Nordvik have pointed out, by 1910 Canada was no longer a shipping power. Norwegians and Swedes purchased many of the Stairs' vessels at a time when other Maritimers were also "turning their backs on the sea." ${ }^{85}$ The family remained in the industry long after most of their regional confrères had exited from it, but they were also amongst the biggest investors in the emerging new "National Policy" economy. They too, saw opportunities in the continental economy rather than in the carrying trades.

82 MHA, Vessel and Owners Registry; Lloyd's Register, 1906-07. Campbell would also become president of the Bank of Nova Scotia, 1923-27.

83 MHA, Vessel and Owners Registry; Lloyd's List, 1902-12; See also Morning Chronicle, 23 June 1902, which mentions NSSC had built two ships in the "old country." The Industrial Advocate (July 1902) reported "Nova Scotia Steel and Coal Co. has purchased the Lawson Wharf on Lower Water St., Halifax...It is understood that the company will make the headquarters for the fleet of steamers being acquired."

84 Frost, "The Aborted British Invasion."

85 Lewis R. Fischer and Helge W. Nordvik, "Floating Capital: Investment in the Canadian and Norwegian Merchant Marines in Comparative Perspective, 1850-1914," ScandinavianCanadian Studies 3 (1988), 17-42. 
Table 6: Stairs Family Vessels*, 1826-1926 (continues next page.)

\begin{tabular}{|c|c|c|c|c|c|}
\hline Vessel Name & Rig & Tonnage & Years Owned & Owner(s) & $\begin{array}{l}\text { No. Shares } \\
\text { / } 64\end{array}$ \\
\hline Atlantic & ship & 331 & 1826 & William Stairs & 12 \\
\hline Corsair & brig/barque & 282 & $1826-38$ & $"$ & 16 \\
\hline Halifax & ship & 344 & $1828-38$ & & 6.4 \\
\hline Rachel + Ellen & brig & 98 & $1829-30$ & $"$ & 64 \\
\hline John Porter & ship & 238 & $1829-40$ & $"$ & 32 \\
\hline Sir Charles Ogle & steamship & 76 & 1830 & HSBC & 64 \\
\hline Rambler & schooner & 76 & $1832-25$ & William Stairs & 64 \\
\hline Clio & barque & 474 & $1837-43$ & & 22 \\
\hline Trial & brigantine & 158 & $1838-40$ & $"$ & 64 \\
\hline Cornwall & schooner & 176 & $1841-45$ & $"$ & 64 \\
\hline Mic Mac & steamship & 102 & 1845 & HSBC & 64 \\
\hline Jerome & brigantine & 132 & $1854-1900$ & Rob't Morrow & 64 \\
\hline Euphrasynt & barque & 382 & $1855-56$ & Rob't Morrow & 64 \\
\hline W. Stairs & barque & 90 & $1860-62$ & W.J. Stairs & 48 \\
\hline Tangier & ship & 966 & $1861-62$ & $"$ & 64 \\
\hline Viking & barque & 598 & $1862-68$ & $"$ & 25 \\
\hline Nova & barque & 312 & 1863 & $"$ & 48 \\
\hline Norn & barque & 254 & $1863-70$ & $"$ & 16 \\
\hline Chebucto & steamship & 65 & 1865 & $\mathrm{HSBC}$ & 64 \\
\hline Alice Roy & barque & 610 & $1866-81$ & W.J. Stairs & 16 \\
\hline Elizabeth & barque & 249 & $1868-74$ & $"$ & 16 \\
\hline Quartette & schooner & 64 & $1868-1903$ & R. Morrow / J.F. Stairs & 64 \\
\hline William & barque & 713 & $1869-88$ & W.J. Stairs & 16 \\
\hline Ragnar & ship & 927 & $1871-97$ & " & 8 \\
\hline William Douglas & ship & 1263 & $1875-89$ & $"$ & 32 \\
\hline Warrior & schooner & 102 & $1875-1905$ & " & 16 \\
\hline Bedford & ship & 1178 & $1877-91$ & $"$ & 16 \\
\hline Elba & barquentine & 308 & $1877-82$ & $"$ & 64 \\
\hline Terra Nova & schooner & 218 & $1877-85$ & $"$ & 32 \\
\hline Esther Roy & ship & 1533 & $1877-96$ & $"$ & 16 \\
\hline
\end{tabular}




\begin{tabular}{|c|c|c|c|c|c|}
\hline Vessel Name & Rig & Tonnage & Years Owned & Owner(s) & $\begin{array}{l}\text { No. Shares } \\
\text { / } 64\end{array}$ \\
\hline W.J. Stairs & barque & 1065 & $1879-82$ & $"$ & 12 \\
\hline Stanley & brigantine & 345 & $1882-83$ & & 32 \\
\hline Wenona & barquentine & 530 & $1882-83$ & $"$ & 64 \\
\hline Eillan Donan & brigantine & 269 & $1883-84$ & $"$ & 64 \\
\hline Sicily & steamship & 1078 & $1883-84$ & HNSC & 64 \\
\hline Kate Melick & barque & 759 & $1883-84$ & W.J. Stairs & 8 \\
\hline Osmond O'Brien & barque & 878 & $1883-94$ & $"$ & 8 \\
\hline Linden & barque & 913 & $1883-94$ & $"$ & 2 \\
\hline R. Morrow & barque & 1156 & 1884-1906 & & 12 \\
\hline Osberga & barque & 1158 & $1884-1908$ & $"$ & 16 \\
\hline Craigie Burn & barque & 1121 & $1885-88$ & & 8 \\
\hline Chas Duncan & schooner & 156 & 1886 & WSS\&M & 32 \\
\hline Avonia & barque & 1664 & $1886-1904$ & & 4 \\
\hline Dartmouth & steamship & 196 & 1888 & HSBC & 2 \\
\hline Kathleen & barquentine & 235 & $1890-94$ & WSS\&M & $?$ \\
\hline Gleaner & schooner & 86 & $1890-1900$ & W.J. Stairs & 16 \\
\hline Savona & ship & 1649 & $1892-1907$ & WSS\&M & 2 \\
\hline Launberga & barque & 1215 & $1894-98$ & WSS\&M & 7 \\
\hline Pekin & steamship & 85 & $1900-1901$ & WSS\&M & 64 \\
\hline Wasis & steamship & 480 & $1902-15$ & NSSC & 64 \\
\hline Wobun & steamship & 1551 & $1902-12$ & NSSC & 64 \\
\hline Urania & steamship & $?$ & 1902 & NSSC & 64 \\
\hline Village Belle & schooner & 129 & $1907-1912$ & WSS\&M & 64 \\
\hline Calberga & barque & 1406 & $1910-15$ & WSS\&M & 64 \\
\hline Benjamin C. Smith & schooner & 100 & $1911-22$ & WSS\&M & 4 \\
\hline Joyce M. Smith & schooner & 112 & $1920-25$ & WSS\&M & 4 \\
\hline Con Rein & schooner & $?$ & $?$ & WSS\&M & $?$ \\
\hline
\end{tabular}

Table 6: Stairs Family Vessels*, 1826-1926.

$\mathrm{HSBC}=$ Halifax Steam Boat Co.

HNSC $=$ Halifax Steam Navigation Co.

NSSC $=$ Nova Scotia Steel and Coal Co. (John F. Stairs Pres.)

*excludes vessels of John Stairs and family yachts. 